\title{
The relation between maternal work hours and cognitive outcomes of young school-aged children
}

Citation for published version (APA):

Künn-Nelen, A. C., de Grip, A., \& Fouarge, D. (2013). The relation between maternal work hours and cognitive outcomes of young school-aged children. ROA. ROA Research Memoranda No. 007 https://doi.org/10.26481/umaror.2013007

Document status and date:

Published: 01/01/2013

DOI:

10.26481/umaror.2013007

Document Version:

Publisher's PDF, also known as Version of record

\section{Please check the document version of this publication:}

- A submitted manuscript is the version of the article upon submission and before peer-review. There can be important differences between the submitted version and the official published version of record.

People interested in the research are advised to contact the author for the final version of the publication, or visit the DOI to the publisher's website.

- The final author version and the galley proof are versions of the publication after peer review.

- The final published version features the final layout of the paper including the volume, issue and page numbers.

Link to publication

\footnotetext{
General rights rights.

- You may freely distribute the URL identifying the publication in the public portal. please follow below link for the End User Agreement:

www.umlib.nl/taverne-license

Take down policy

If you believe that this document breaches copyright please contact us at:

repository@maastrichtuniversity.nl

providing details and we will investigate your claim.
}

Copyright and moral rights for the publications made accessible in the public portal are retained by the authors and/or other copyright owners and it is a condition of accessing publications that users recognise and abide by the legal requirements associated with these

- Users may download and print one copy of any publication from the public portal for the purpose of private study or research.

- You may not further distribute the material or use it for any profit-making activity or commercial gain

If the publication is distributed under the terms of Article $25 \mathrm{fa}$ of the Dutch Copyright Act, indicated by the "Taverne" license above, 
The relation between maternal work hours and cognitive outcomes of young school-aged children

Annemarie Künn-Nelen

Andries de Grip

Didier Fouarge

\section{ROA Research Memorandum}

ROA-RM-2013/7

Research Centre for Education and the Labour Market Maastricht University

P.O. Box 616, 6200 MD Maastricht, The Netherlands

$\mathrm{T}+31433883647 \mathrm{~F}+31433884914$

secretary-roa-sbe@maastrichtuniversity.n www.roa.nl 


\title{
The relation between maternal work hours and cognitive outcomes of young school-aged children
}

\author{
Annemarie Künn-Nelen \\ Andries de Grip \\ Didier Fouarge
}

ROA-RM-2013/7*

March 2013

Research Centre for Education and the Labour Market

Maastricht University

P.O. Box 616, 6200 MD Maastricht, The Netherlands

$\mathrm{T}+31433883647 \mathrm{~F}+31433884914$

secretary-roa-sbe@maastrichtuniversity.nl

www.roa.nl

\footnotetext{
* The ROA Research Memorandum Series was created in order to make research results available for discussion, before those results are submitted for publication in journals.
} 


\section{Abstract \\ The relation between maternal work hours and cognitive outcomes of young school- aged children**}

This paper is the first that analyzes the relation between maternal work hours and the cognitive outcomes of young school-going children. When children attend school, the potential time working mothers miss out with their children, is smaller than when children do not yet attend school. At the same time, working might benefit children through, for example, greater family income. Our study is highly relevant for public policy as in most countries maternal employment rates rise when children enter school. We find no negative relation between maternal working hours and child outcomes as is often found for pre-school aged children. Instead, we find that children's sorting test score is higher when their mothers work part-time (girls) or full-time (boys). Furthermore, we find that planned parent-child activities are positively related to children's language test scores. Nevertheless, we do not find that a richer home environment in terms of the number of parent-child activities provided to the child explain the relation between maternal work hours and children's test scores.

JEL classification: D10, J13, J22

Keywords: Intergenerational human capital investments, (non)cognitive skills, maternal labor supply

Annemarie Künn-Nelen

Andries de Grip

ROA

ROA

Maastricht University

Maastricht University

P.O. Box 616

P.O. Box 616

6200 MD Maastricht

6200 MD Maastricht

The Netherlands

The Netherlands

a.kuenn@maastrichtuniversity.nl a.degrip@maastrichtuniversity.nl and IZA and IZA

Didier Fouarge

ROA

Maastricht University

P.O. Box 616

6200 MD Maastricht

The Netherlands

d.fouarge@maastrichtuniversity.nl

\footnotetext{
** We thank Lex Borghans, Thomas Dohmen, Trudie Schils, Maria Zumbühl, Thomas Zwick and participants of the 2010 Verein für Socialpolitik and the DUHR seminar for useful comments and suggestions. Moreover, we thank the research institute KAANS for providing the Moelejaan data, and Paul Jungbluth and Elma Nap-Kolhoff for data support.
} 


\section{Introduction}

Several studies deal with the relation between maternal employment and child outcomes (e.g., Ermisch and Francesconi 2002; Harvey 1999; Vandell and Ramanan 1992; Desai et al. 1989). However, most studies have concentrated on maternal work status before children go to school. Although various studies have provided contradictory evidence, most studies found a negative relation between maternal employment and child outcomes (e.g., Ruhm 2004; Baum 2003; Ermisch and Francesconi 2000).

Also public policies related to parental leave schemes focus on preschoolaged children. Therefore, most mothers with children below the age of four often do not participate in the labor market or they choose to work parttime. Whereas there is great heterogeneity in the generosity of parental leave schemes, in most European countries these schemes end before children go to school $\left.\right|^{1}$ Nevertheless, working full-time may have adverse effects on children's development when children go to school as well, since, in general, a child's school week is shorter than a full-time work week. Mothers of school-aged children may therefore choose not to work or to work part-time. This is what Table 1 shows. For five European countries, data on maternal

\footnotetext{
${ }^{1}$ There is great variation in parental leave schemes across countries. The United States is the only Western country in which parents do not get any paid leave: Each parent has the right to take 12 unpaid weeks. In other Western countries, leave schemes are more generous. In the United Kingdom, for example, mothers get 52 weeks of paid leave and both parents get 13 weeks of unpaid leave. In Germany, mothers get 14 weeks fully paid; thereafter parents get 12 or 14 months, during which they are paid $65 \%$ of their previous wage with a certain maximum, depending on whether both parents decide for parental paid leave. Moreover, both parents together have the right to receive three years of unpaid leave before the child turns five years old. In the Netherlands, mothers get 16 weeks of fully paid maternity leave; thereafter both parents get 26 weeks of unpaid leave. This parental leave can be taken discontinuously and before the child turns eight years old.
} 
employment is provided. Whereas the labor force participation of mothers with children aged between 5 and 14 is around $75 \%$ in all countries except for Spain, the number of average work hours is below 33 hours per week. This implies that mothers with school-aged children usually choose a parttime job. While in most countries the labor supply of mothers increases as the youngest child grows older, this is not the case in the Netherlands. The labor supply of Dutch mothers remains low, irrespective of the age of the youngest child. Several studies have shown that this is due to the preference of mothers to combine work with child care (e.g., Fouarge and Muffels 2008) 2 $^{2}$ Although Table 1 shows that mothers of (young) school-aged children tend to work part-time, research on the relation between maternal work status while children attend school and child outcomes is sparse.

[Table 1 around here]

In this paper, we fill the gap in the literature by analyzing the relation between maternal work hours and the cognitive outcomes of young schoolgoing children. When children go to school, the potential time working mothers miss out spending with their children is shorter than when children do not yet attend school. When mothers' work hours match their children's school hours, part-time working mothers can spend the same amount of time with their children as non-working mothers. Moreover, working may benefit children through greater family income (e.g., Aughinbaugh and Gittleman 2003;

\footnotetext{
${ }^{2}$ Among Southern European countries, such as Spain, the main reason females work part-time is constraints in the labor supply due to the unavailability of jobs with longer hours.
} 
Blau 1999). Family income can be used for both good nutrition and a rich home environment that stimulates child development (e.g., Fox, Han, Ruhm, and Waldfogel 2013). Part-time work can therefore have the advantage that mothers can work during school hours and at the same time contribute to family income. As neither income nor parental time spent with children is included in our data set, we cannot directly test these hypotheses. Instead, we test the relation between maternal work hours and child outcomes, and whether a quantitative measure for a rich home environment - the number of parent-child activities - can explain this relation. The unique data set we use contains information on Dutch children in their first 2 years of regular, mandatory primary school. Though a compulsory school age of 5 , the large majority of children enter school at the age of 4 . The data builds on two sources: language and sorting test scores that were administered in the first as well as the second year in school are provided by schools, and information on parental, child (including personality traits), and family characteristics provided by parents.

The Dutch education system provides a good setting for analyzing the relation between maternal work status and the cognitive outcomes of young school-aged children. Children enter school at the age of four and attend two years of preparatory classes. So even though the children in our data set already attend school, they do not yet have classes in reading, writing, or arithmetic $S^{3}$ In both the first and the second school years, children were tested on their language and sorting skills via validated national tests from Cito, the official national testing institute. The test scores therefore mainly

\footnotetext{
${ }^{3}$ So these first two years are comparable to mandatory kindergarten.
} 
reflect children's initial abilities and parental influences, but not the cognitive input from school. Although our focus is on the correlation between the work status of mothers and child outcomes, our focus on young children who are not yet graded in school lowers the risk of reverse causality that occurs when mothers have adapted their work hours to children's grades in school.

We estimate a value-added model of production of cognition (cf. Todd and Wolpin 2007) with school fixed-effects, in which we regress children's second year's test scores on their first year's score, their cognitive skills, maternal work hours, home environment and other variables. We find that whereas children's language test score is not related to maternal work status, their sorting test score does depend on maternal work status. We find that this relation is different for girls than for boys. Girls perform best when their mothers have a part-time job of at least 12 and at most 32 hours per week, whereas boys perform best when their mothers work full-time. However, we do not find any evidence that a rich home environment plays a role in the relation between maternal employment status and child outcomes in their second year at school (approximately at the age of five).

The structure of this paper is as follows: The next section briefly reviews the related literature. Section 3 describes the data and provides sample statistics. Section 4 presents the empirical strategy. Section 5 reports the results. Section 6 discusses the results and concludes the study. 


\section{Related literature}

In their seminal paper, Todd and Wolpin (2007) investigated the theory and empirical implications of the production of cognition in children with a specific focus on family inputs and school inputs. They conclude that a value-added model best fits the notion that a child's cognitive development is a cumulative process that builds on own endowments and inputs from the family and school. We build forth on this framework in Section 4. Although Todd and Wolpin (2007) do not explicitly deal with the relation between maternal employment and child outcomes, there is an extensive literature that does so. This literature questions whether children profit more from a non-working mother who takes care of her child herself or from a mother who works, thereby contributing to family income, but sends her child - at least for some days per week - to formal or informal child care. Only a few studies have distinguished between part-time and full-time maternal employment. The literature provides contradictory evidence on the effect of parents' work time on their children's school performance. Harvey (1999), Greenstein (1995), and Parcel and Menaghan (1994) found no detrimental effects of early maternal employment on child development ${ }^{4}$ However, other studies have provided evidence of a negative effect of early maternal employment on child outcomes.

Baum (2003) found that maternal paid work in a child's first year has detrimental effects on the child's cognitive development. Additionally, the author found that working during the first quarter after childbirth de-

\footnotetext{
${ }^{4}$ These studies include children from the age 3 to 12 .
} 
creases child outcomes (as measured by the Peabody Picture Vocabulary Test). Moreover, his results suggested that increased family income from maternal work partially offsets the negative effects of maternal employment. Ruhm (2004) showed that maternal employment during the first three years of a child's life has a negative effect on the cognitive abilities of children aged five and six years old. The effects found are greater for reading and mathematics than for verbal abilities. Evidence shows more favorable outcomes when mothers work part-time than full-time when the child is two or three years old. Using the British Household Panel Study, Ermisch and Francesconi (2000) found a negative effect of mothers' full-time employment during the time the child is zero to five years old on the child's educational attainment as a young adult. The effect of mothers' part-time employment status is also negative, but lesser and insignificant. Similarly, the effect of fathers' employment is small and negative but not always significant. Vandell and Ramanan (1992) showed that early maternal employment has a positive effect on reading and math scores for disadvantaged children.

Contradictory findings may not just result from differences in the time periods analyzed, data sets used, and methodologies applied, but may also be due to the difficulty of analyzing the relation between maternal work hours and child outcomes $5^{5}$ Ruhm (2004) suggested that the labor supply decision of parents seems to involve a trade-off between time and goods investments in children. Since there is no data set that includes information on parental

\footnotetext{
${ }^{5}$ All studies address the endogenous character of maternal employment in some way or the other. This ranges from including a large set of confounding factors to reduce unobserved heterogeneity (e.g., Ruhm 2004) to dynamic sibling fixed effect models (Ermisch and Francesconi 2000) and instrumental variables analyses in which local labor market conditions are used to estimate maternal employment (Baum 2003).
} 
work hours, parental time investments, family income, and child outcomes, it is difficult to analyze whether and how parental work hours affect child outcomes. However, there have been studies examining parental work hours, on the one hand, and time or goods investments, on the other.

First, parental work hours affect the time parents have available for spending with their child, but this relation does not have to be one to one. Using US time use data, Bianchi (2000) showed that, compared to nonworking mothers, working mothers selectively reduce their own leisure time, sleeping time, and time devoted to home production other than child care. As a result, mothers with paid employment spend, on average, nearly as many hours in direct child interactions as non-employed mothers. However, other studies found that working parents spend less time with their children than non-working parents. For example, Fox, Han, Ruhm, and Waldfogel (2013) found that employed mothers spend significantly less time in primary childcare than their non-employed counterparts. Cawley and Liu $(2007)$ analyzed whether working mothers spend less time on specific parent-child activities than non-working mothers and found that employed women spend significantly less time reading to their children, helping with homework, and in educational activities in general. The authors found no evidence that these decreases in the time spent with children were offset by increases in the time husbands spent with children. Thereby, the authors suggested that lower parental time investments may explain the frequently (but not always) found negative association between maternal employment and children's cognitive development in the United States. 
Second, parental work hours affect family income. This, in turn, may affect child outcomes through good nutrition and a home environment that focuses on child development (e.g., Aughinbaugh and Gittleman 2003; Blau 1999). For example, Fox, Han, Ruhm, and Waldfogel (2013) found that the increase in market work during the last centuries is accompanied by a rise in family income in the typical US two-parent family. Moreover, Kornrich and Furstenberg (2013) found a gap in child expenditures between rich and poor parents. Ruhm (2008) analyzed more precisely whether home environment is the driving force in the relation between early maternal employment and later child outcomes (aged 10-11). The author's analyses on child outcomes included a variable measuring the home environment that consists of a mix of observational and parent-reported items assessing the emotional support and cognitive stimulation received by children through their home environment, planned events, and family surroundings. Ruhm found that a better home environment benefits child outcomes. Negative, though not always significant, signs of the interaction terms with maternal work hours suggest that this positive effect of home environment is smaller when mothers work more hours.

\section{Data and descriptive statistics}

\subsection{Dutch early school system}

In the Netherlands, parents are free to choose a primary school for their children. Attending school is obligatory from the age of five on. However, 
$98 \%$ children enter primary school at the age of four (CBS 2003) ${ }^{6}$ The first two years of primary school in the Netherlands are comparable with kindergarten, though obligatory from the age of five. At this age, children merely have preparatory activities. Only from the third school year onward do children have classes in reading, writing, and arithmetic. During the first two school years, children have to go to school for about 900 hours per year, which boils down to about 30 hours per week.7

Nevertheless, in most schools, children are tested on their language and sorting skills halfway through the first and second school years. These tests are developed and validated by the national testing institute Cito to determine possible cognitive problems at an early age. Although schools are not obliged to test children, about $62 \%$ of all schools test their pupils in the first school year, with this percentage increasing to $76 \%$ in the second school year (Jungbluth and Rodigas 2011).

\subsection{Data}

This paper uses the Moelejaan data from research institute KAANS at Maastricht University. The Moelejaan project focuses on preschool and earlyschool education in the southern part of the Dutch province of Limburg. The data set builds on two sources: test scores provided by schools and survey information from parents.

\footnotetext{
${ }^{6}$ The age of children at the time they perform the tests is included in the analyses to take into account their age when entering school.

${ }^{7}$ By law, schools must provide at least 880 hours and at most 940 hours of education per year. Most children have Wednesday afternoon off, but schools are free to institute their own schedules (source: http://www.rijksoverheid.nl/onderwerpen/schooltijden-enonderwijstijd).
} 
Information from schools Test scores are provided from schools. Children were tested twice, halfway the first and second school years, by which $98 \%$ of the children are aged four to five. Children are tested on their sorting and language skills. We have information on these tests from two cohorts of children: Cohorts 1 and 2 took the tests in the first school year around January 2007 and January 2008, respectively, and in the second school year around January 2008 and January 2009, respectively 8

Parental questionnaire All parents of children attending the first two school years of all primary schools in the southern part of Limburg received a questionnaire via the school in September 2008.9 Parents could return the questionnaire to the school in a sealed envelope. The survey data contains information on parental work time, as well as information on activities parents undertake with their childr. Moreover, the survey data includes detailed information on the child (e.g., various behavior characteristics and non-cognitive skills), the parents (e.g., educational level, parental views, and parenting goals), and the household (e.g., the number of children and the presence of other adults).

About $60 \%$ of all children attending the second year of primary school were tested both in the first and second school years. Although the response rate of the parental questionnaire was almost $70 \%$, only $45 \%$ of the parents completed the full survey. Therefore, our sample contains complete informa-

\footnotetext{
${ }^{8}$ There are some exceptions: $2 \%$ of the children attended the first year of primary school twice. For these children, we use their first test scores to make sure the test scores are comparable to those children who did not attend the first year of school twice.

${ }^{9}$ One questionnaire per child, with the child's name, address, date of birth, and gender at the top.
} 
tion on 2,315 children. Since some children only completed one type of test, our sample sizes for the analyses on child outcomes differ. Our sample for the language test includes 2,260 children, whereas that for the sorting test includes 1,895 children ${ }^{10}$ Table 2, reports the sample sizes for boys and girls, as the various analyses are performed separately by gender.

[Table 2 around here]

Human capital outcomes We use two test scores for children's cognitive skills: language and sorting. During the tests, the children worked in their own assignment books. The teacher read the assignment out loud and the children had to mark what they believed was the correct answer. The tests consisted of two parts, both taking about 20 to 30 minutes. The tests were similar in the first and second years and for both cohorts of children. The test scores are the number of good answers.

The language test deals with passive vocabulary and critical listening, and involves 56 assignments. The sorting test involves 42 assignments that focus on three sorting principles: classifying subjects (placing them next to each other), ranking subjects, and comparing and counting them.

[Table 3 around here]

\footnotetext{
${ }^{10}$ The sample of children included seems to be slightly positively selected. Children in our sample score on average one point per test higher than children from whom the parents did not complete the survey. For the distribution of test scores of the sample and the population, see Figure 5 in the appendix.
} 
Table 3 reports the raw test scores ${ }^{11}$ On average, the children have 47 out of 56 questions right on the language test. With respect to the sorting test, the children have on average, about 34 out of 42 questions right. Group mean comparison tests show that girls perform significantly better in both tests than boys ${ }^{12}$

Maternal work status The questionnaire provides information on parental work time. The responding parent is asked to report whether she/he and her/his partner worked and, if so, how many hours a week in the following ways: not working, working in a small part-time job (fewer than 12 hours a week), a large part-time job (12 to 32 hours a week), or working in a fulltime job (more than 32 hours a week). Figure 1 reports the distribution of maternal and paternal work status. Most children (64\%) have a mother with a large part-time job, $15 \%$ of the children has a mother who works full-time, and $5 \%$ has a mother with a small part-time job. The remaining $16 \%$ of the children has a mother without a paid job. We use the latter as the reference category in the analyses. Since almost all fathers in the sample work full-time, we control for paternal work status but do not focus on the role it plays on child outcomes. About $4.5 \%$ of the fathers have a part-time job, and $3 \%$ of the children has a father without a paid job.The distribution of parental work hours is identical for boys and girls.

\footnotetext{
${ }^{11}$ These test scores are from the test in children's second year of school. In the Appendix, Table 6. one finds the descriptive statistics on the test scores in school year one.

${ }^{12}$ Since the girls are not significantly older (in days) than the boys, this finding does not seem be due to differences in age.
} 
[Figure 1 around here]

Rich home environment By a rich home environment, we mean that a child has access to a large variety of home inputs. We measure this by two sets of survey questions on joint parent-child activities: daily activities and planned activities ${ }^{13}$ We include the number of activities parents undertake with their child in the analyses on child outcomes. Thereby, we analyze whether the relation between maternal work status and child outcomes is driven by children's home environment, that is, the number of parent-child activities provided at home.

Questions related to joint daily activities are asked in the following way: In their joint daily activities, children do lots of things together with their parents. What applies to your child? The activities referred to are the following:

- Watching children's programs on TV with your child

- Watching TV/video (other programs) with your child

- Playing with toys inside with your child

- Playing outside with your child

- Playing on a computer with your child

- Drawing/painting with your child
- Making up stories with your child

- Going to the sports club or swimming pool with your child

- Reading stories to your child

- Reading stories focused on development to your child

- Talking about school with your child

\footnotetext{
${ }^{13}$ Our focus is on the richness of a child's environment in terms of the quantity of joint activities provided. Of course, the quality of the home environment provided is important for the richness as well.
} 
We know when at least one of the parents undertook the abovementioned activities with their child, but we do not know which parent. We construct a variable measuring the number of joint activities parents undertook with their child 14

Questions dealing with planned activities are asked in the following way: When was the last time you (or your partner) went on a trip together with your child? The trips referred to are the following:

- Visiting a museum with your child

- Going to a swimming pool with your child

- Going to a sports club with your child

- Going to a zoo with your child
- Going to a library with your child

- Going to a park or forest with your child

- Going to an amusement park with your child

Possible answers are 'today', 'in the last week', 'some weeks ago', 'some months ago', 'more than half a year ago', and 'I rarely do'. 'I rarely do' was coded zero and all other answers were coded one. We then calculated an index for the number of joined planned activities as the sum of all activities parents undertake with their child.

[Figure 2 around here]

\footnotetext{
${ }^{14}$ Results are similar when leaving out the items for which the direction of the parentchild interaction is less obvious "Watching children's programs on TV with your child" and "Watching TV/video (other programs) with your child".
} 
Figure 2 plots the distribution of the number of joint daily and planned activities: Panel (a) shows that only a few parents undertake less than five joint daily activities with their child. About $10 \%$ of the parents undertake 7 out of the 11 activities with their child. Undertaking 9, 10, or even 11 joint activities is most common in the sample. Panel (b) shows that most parents undertake at least five out of eight planned activities with their child. Both distributions seem to be truncated 15

Control variables The questionnaire contains detailed information on the children, their parents, and the household the children live in. As suggested by earlier research, we control for parental education levels (e.g., Carneiro, Meghir, Parey, and Street 2007). Additionally, we include test scores in the first year at school to control for the children's human capital level at school entrance. We only show these two key control variables in the estimation tables.

Other control variables are also included but not reported in the tables with the estimation results. With respect to the children, we include the following control variables: a cohort dummy, a dummy for whether the child speaks Dutch with friends, and a variable denoting religion of the child. We also include additional control variables for the socio-emotional context of the child. We know whether a fundamental event occurred that may have had consequences for the child's development (e.g., 'divorce of the parents') and the extent to which the child suffers from difficulties with respect

\footnotetext{
${ }^{15}$ This suggests that not all activities parents undertake with their children are mentioned in the questionnaire. However, since the distribution is similar for boys and girls, this is not a problem in our analyses.
} 
to emotions, concentration, behavior, and relationships with other people. Moreover, the parental questionnaire includes 50 items on the child's noncognitive skills. Factor analyses show that we can distinguish four factors, related to the following characteristics: inquisitive (e.g., 'interested'), individual (e.g., 'independent'), difficult (e.g., 'bothersome'), and sociable (e.g., 'oriented toward other children'). The standardized values of these factors are included in all estimations on children's outcomes 16

Regarding the parents, we include in addition to their educational level their age, religion, and whether they speak Dutch with their child. We also have information on various parental views and parenting goals. These variables may convey information on heterogeneity in parenting style. Parental views are measured by the extent to which they agree to 16 statements (e.g., 'child care is important for children's development') on a five-point Likert scale. With respect to parenting goals, parents were asked to state how they view the importance of 12 goals for their children (e.g., 'developing imagination') on a five-point Likert scale. The analyses include parental values and parenting goals measured by two standardized factors constructed by factor analysis. At the household level, we include the number of children living in the household and whether or not there are grandparents, uncles or aunts, or other adults living in the household. Summary statistics of the control variables are reported in Table 7 in the appendix ${ }^{17}$

\footnotetext{
${ }^{16}$ The factor loadings for this factor analysis and the upcoming ones can be found in Table 8 to 10 in the appendix.

${ }^{17}$ We do not have data on parental income. We do have information on the number of child books available in the household. This is often used as a proxy for parental income. In our dataset, this variable is not related to child outcomes and inclusion of this variable thereby does not affect our results.
} 
Because we have school identifiers, we include school fixed effects to control for differences in school performance and school environment. Since the average distance between home and school for children attending primary school in Limburg is $0.7 \mathrm{~km}$, we thereby indirectly control for differences in neighborhood characteristics as well, which is important as shown by for example Sastry and Pebley (2010) ${ }^{18}$

\subsection{Descriptive evidence}

Figures 3 and 4 plot the distributions of the two test scores by maternal work status and gender. Figure 3 does not show a significant difference in either the mean or the distribution of the language test score for children with working and non-working mothers. Moreover, whether a mother works part-time or full-time does not seem to matter. This is in sharp contrast to Figure 4 , where for both girls and boys the distributions of sorting test scores seem to be shifted to the right and more compressed when the mother has a large part-time or full-time job, compared to the distributions for children with a mother with a small part-time job or without a paid job. While the mean standardized test scores for girls are highest when their mothers had a large part-time job, those for boys were highest when their mothers had a full-time job. This difference is small and may be caused by other factors driving both maternal work hours and child outcomes, such as maternal education. Section 5 analyzes whether maternal work status indeed matters for

\footnotetext{
${ }^{18}$ Source: CBS Statline. Regional information: Limburg: years 2006, 2007, 2008.
} 
child outcomes while controlling for, among other things, parental education.

[Figure 3 around here]

[Figure 4 around here]

\section{Empirical strategy}

Value-added model We estimate a value-added model of production of cognition (see Todd and Wolpin 2007). In this model, a lagged measure of cognitive achievement is included as an explanatory variable since data on past inputs are unavailable. 19 The model is as follows:

$$
C_{i h s k, t=1}=\alpha_{k}+\beta_{k} L_{i h s k, t=1}+\gamma_{k} X_{i h s k, t=1}+\lambda_{k} C_{i h s k, t=0}+\epsilon_{i h s k, t=1}
$$

where $C_{i h s k, t}$ is the test score from child $i$, in household $h$, in school $s$ of test $k$ at time $t . L_{i h s k, t=1}$ is the vector of coefficients denoting parental working hours and $X_{i h s k, t=1}$ is the vector denoting control variables. All input and control variables are measured at time $t=1 . C_{i h s k, t=0}$ denotes the lagged test score. Like Todd and Wolpin (2007), we assume that the error term contains four additive components.

$$
\epsilon_{i h s k, t=1}=\varepsilon_{i}+\varepsilon_{h}+\varepsilon_{s}+\zeta_{i h s k, t=1}
$$

\footnotetext{
${ }^{19}$ There is one measure for parental inputs in the data: For some of the children we do have information on preschool attendance, but as including preschool attendance did not change the results to a large extent and at the same reduced the sample, we do not report these findings.
} 
where $\varepsilon_{i}, \varepsilon_{h}$, and $\varepsilon_{s}$ denote child, family and school fixed effects, respectively, and $\zeta_{i h s k, t=1}$ denotes the idiosyncratic error.

Empirical model In our empirical model, we are able to control for schoolfixed effects. Even though we are not able to include child and householdfixed effects ${ }^{20}$ the dataset at hand is very elaborate on child and household characteristics. The inclusion of this detailed information reduces the risk of bias due to unobserved heterogeneity with respect to child and household characteristics. The estimated model is as follows:

$$
\begin{aligned}
C_{i h s k, 1} & =\alpha_{k}^{\prime}+\beta_{k 1}^{\prime} P T s_{m}+\beta_{k 2}^{\prime} P T l_{m}+\beta_{k 3}^{\prime} F T_{m} \\
& +\gamma_{k 1}^{\prime} N W_{f}+\gamma_{k 2}^{\prime} P T_{f}+\delta_{k}^{\prime} \mathbf{X}_{i h s}+\eta_{k}^{\prime} \mathbf{C}_{i h s k, 0} \\
& +\lambda_{k}^{\prime} \mathbf{N C}_{i}+\pi_{k}^{\prime} \mathbf{D}_{i} \\
& +\theta_{k}^{\prime} D A_{h}+\kappa_{k}^{\prime} P A_{h}+\phi_{k}^{\prime} P G_{h}+\varphi_{k}^{\prime} P S_{h} \\
& +\varepsilon_{s}^{\prime}+\zeta_{i h s k}^{\prime}
\end{aligned}
$$

where $P T s_{m}, P T l_{m}$, and $F T_{m}$ are dummy variables that denote whether the mother has a small part-time job, a large part-time job, or a full-time job, respectively. The reference group consists of mothers without a paid job. For fathers, we include two dummy variables denoting deviation from full-time employment, which is the most common work status. We include a dummy for having no paid employment $\left(N W_{f}\right)$ and another for having a part-time

\footnotetext{
${ }^{20}$ Whereas we have two observations for test scores, we only have one observation for input variables. Since we have school information on children attending the first and second year of compulsory kindergarten, we cannot do sibling-fixed effects either.
} 
job $\left(P T_{f}\right)$. Because the number of fathers belonging to either of these two categories is very small, we do not report these coefficients.

The vector $\mathbf{X}$ denotes usual control variables as described in Section 3 . It includes for example the education level of the parents and the number of siblings. The variable $C_{i h s k, 0}$ denotes children's test scores in their first year at primary school. ${ }^{21}$

We proxy for child fixed effects $\left(\varepsilon_{i}\right)$ by including a large set of variables measuring children's personality traits. The vector $\mathbf{N C}$ consists of four standardized factors related to children's non-cognitive skills (see Section 3 for details). This vector takes out a large part of the normally unobserved heterogeneity across children. Moreover, we include a vector with dummy variables (NC) whether the child suffers from difficulties with respect to emotions, concentration, behavior, and relationships with other people.

To reduce unobserved heterogeneity across households $\left(\varepsilon_{h}\right)$, we include the number of joint daily $\left(D A_{h}\right)$ and planned activities $\left(P A_{h}\right)$ parents undertake with their children. Next to these proxies for home environment, we moreover include two standardized factors relating to parenting goals $(P G)$ and parental styles $(P S)$. So even without panel data, we are able to reduce the unobserved heterogeneity with respect to both child and household characteristics to a large extent ${ }^{22}$

\footnotetext{
${ }^{21}$ When the test scores from the first year are omitted, the education level of the mother becomes more important. The role of maternal employment is robust to omitting earlier test scores in all analyses.

${ }^{22}$ Unfortunately, our data are cross-sectional, with the exception that test scores are measured in two successive years. Therefore, our estimations do not warrant a causal interpretation. However, since the children in our data are very young and have not yet started learning how to read, write, or do arithmetic at school, it is likely that both parental work hours and the number of joint parent-child activities are exogenous with
} 
We estimate Equation (3) separately for boys and girls, since it turns out that maternal work status affects child outcomes differently for boys and girls. To see whether the relation between maternal work status and child outcome is affected by the inclusion of joint activities, in other words, whether the relation between maternal work status and child outcomes is (partly) driven by the richness of the children's home environment, we report regression results without and with the two variables measuring parent-child activities.

\section{Results}

Table 4 reports the ordinary least squares (OLS) results of Equation (3) for girls (Columns (1) and (2)) and boys (Columns (3) and (4)) separately ${ }^{23}$ The estimation results show that maternal work status is not related to children's language test score. Instead, the educational level of the mother seems to be important for children's language test score. The more educated a child's mother, the better the child performs at the language test in the second school

respect to child outcomes, because at preschool ages the child endowments we analyze are not revealed to parents (cf. Ermisch and Francesconi 2000, Rosenzweig and Wolpin 1995). Due to the unique control variables included in the estimations, such as non-cognitive skills, parental views, and parenting goals, unobserved heterogeneity and the associated likelihood of spurious effects is not likely to be a serious issue. There might be another source for endogeneity as well: Parents who are less productive in raising their children could also be less productive in the labor market. This could lead to an upward bias of our findings. Nevertheless, as we include parental education in the analyses to control for this possible source of unobserved heterogeneity, the bias is likely to be small. However, our findings should not be interpreted in a causal way.

${ }^{23}$ Since Figures 3 and 4 , show that the distribution of the test scores is truncated (most children perform well on the test), we performed Tobit analyses when estimating the relation between maternal work status and child outcomes. Since these Tobit estimates are similar to the OLS estimates, we report the OLS estimations in this paper. 
year. Because we control for children's test scores in the first year at school, this finding suggest that children from highly educated mothers experience larger increases in their human capital than those from less educated mothers.

The relation between maternal work status and child outcomes does not change after including the joint parent-child activities in the regression. Nevertheless, we do find that the richness of the home environment as measured by the number of joint planned activities is positively and significantly related to girls' as well as boys' language test scores, although this relation is only weakly significant for girls. ${ }^{24}$ The number of joint daily activities does not seem to relate to children's language test scores. This is somewhat surprising, and suggests that not the quantity of joint daily activities matters for child outcomes is important but rather the quality of joint daily activities, or even parent-child interaction in general. The clear positive relation between maternal education and children's language test score is in line with this idea.

[Table 4 around here]

[Table 5 around here]

Table 5 shows the results from the analyses on the sorting test scores for both girls (Columns (1) and (2)) and boys (Columns (3) and (4)). In contrast to the language test scores, children's sorting test scores appear to relate to maternal work hours. Girls whose mothers have a large part-time

\footnotetext{
${ }^{24}$ The positive relation between joint planned activities and children's language test score is driven by higher educated parents. If we estimate the regressions separately for high and low educated parents, the positive significant relation between joint planned activities and children's language test score is only found for children from highly educated parents.
} 
job perform better than girls whose mothers who do not a paid job 25 We also find that maternal work status plays a role in explaining boys' scores on the sorting test. However, in contrast to girls, boys perform best when their mothers have a full-time job ${ }^{26}$ Additionally, we observe a significant relation between boys' sorting test scores and their fathers' level of education.

Table 5, shows that joint parent-child activities are not significantly related to children's sorting test scores. It comes therefore as no surprise that the relation between test scores and maternal work status is not affected by the inclusion of the number of joint parent-child activities.

Overall, the richness of the home environment does not seem to play a large role for children's test scores. Whereas the number of planned parentchild activities is, at least to some degree, related to children's language test scores, the number of daily parent-child activities are not related to either of the test scores. However, the absence of a clear relation between home environment and child outcomes could imply that not the quantity but the quality of parent-child activities is important for child outcomes ${ }^{27}$

Our findings show that a distinction between the determinants of the test scores of boys and girls is valuable, since boys' and girls' test scores seem to be differently related to maternal work status. Whereas girls with mothers with a large part-time job perform significantly better at the sorting

\footnotetext{
${ }^{25}$ However, the coefficient for full-time working mothers is not statistically different from that of mothers with a large part-time job.

${ }^{26}$ If we perform the analyses jointly for girls and boys, we find a weak positive relation between maternal work hours and children's sorting test score.

${ }^{27}$ The measure of home environment used in Ruhm (2008), includes both quantity and quality measures and is indeed significantly related to child outcomes.
} 
test than girls with mothers without a paid job, boys perform significantly better when their mothers work full-time 28

With respect to the sorting test scores, we find that children benefit when their mothers work. This is probably related to the fact that the children in our sample all attend school about 30 hours a week. The possible difference in the time spent with children between a non-working mother and a mother with a large part-time, or even a full-time job, is therefore much less than when children do not yet attend school. In our sample of young school-aged children, part-time working mothers might be working during school hours. Even in the case where mothers have to work when the children are not at school, the difference in the number of joint parentchild activities between working and non-working mothers seems to be of less importance than the advantages maternal employment can bring. The most straightforward advantage is a higher family income. In our sample, where almost all fathers work full-time, families with a mother with a large parttime or full-time job probably have a higher family income than families in which the mother does not work. This additional income may benefit children by better nutrition and access to goods or services that benefit children's cognitive development. However, we do not find any significant evidence for

\footnotetext{
${ }^{28} \mathrm{We}$ are not aware of studies differentiating between boys and girls when it comes to maternal employment an outcomes of young school-aged children. Literature focusing on the relation between maternal employment (and child care) in the first years of a child's life and child outcomes often do not find differences between boys and girls (Ruhm 2004, Han, Waldfogel, and Brooks-Gunn 2001, Hill, Waldfogel, Brooks-Gunn, and Han 2005). Nevertheless, when differences are found, the relation between maternal employment and child outcomes seems to be more negative for boys than for girls (Brooks-Gunn, Han, and Waldfogel 2002, Desai, Chase-Lansdale, and Michael 1989). This is often attributed to the findings of Zaslow and Hayes (1986) and Rutter (1985) which suggest that boys are more vulnerable than girls in their early childhood.
} 
a richer environment in terms of the number of joint parent-child activities to explain the better cognitive outcomes of children with a mother who works at least 12 hours per week.

In a robustness check, we test the sensitivity of our model to measurement error in the lagged test score. This measurement error might attenuate the coefficient on lagged test scores in value-added estimations and might bias the input coefficients such as maternal employment or the richness of the home environment. To account for this, we follow Andrabi, Das, Khwaja, and Zajonc (2011) and instrument the lagged test score in one subject $\left(C_{i h s k=1, t=0}\right)$ by the lagged test score in an alternative subject $\left(C_{i h s k=2, t=0}\right)$. This approach is valid under the assumption that the measurement in both test scores are uncorrelated. We do not find that such bias affects our results (see appendix).

\section{Conclusion and discussion}

In this paper, we analyze the relation between maternal work status and child outcomes. In contrast to most earlier research, our analyses focus on the work status of mothers of young school-aged children. When children attend school, the potential time working mothers miss out spending with their children is much less than when children do not yet attend school. Mothers who work part-time especially may work entirely during school hours. At the same time, working can benefit children, for example, through greater family income. 
We estimate a value-added model of production of cognition and do not find a negative relation between maternal employment and child outcomes as is often found for preschool aged children. Instead, we find that boys' and girls' sorting test scores are higher when their mothers have a large parttime or full-time job, respectively. In contrast to our expectations, part-time employment - allowing for working during school hours - does not seem to be most beneficial for all children, since boys with full-time working mothers perform better than boys of mothers with a part-time job. Since the test scores for girls with a full-time working mother are as good as those for girls with mothers with another employment status, our findings suggest that full-time employment may be most beneficial for the cognitive outcomes of young school-aged children 29 This finding, that working mothers benefit school-aged children, is in line with the findings of O'Brien and Jones (1999), who found that children aged 13 to 15 perform best when their mother is employed, although these gains are not as strong when both parents work full-time.

We also show that maternal employment benefits children in a way that cannot be explained by a richer home environment in terms of joint parentchild activities. Instead, greater monetary resources might play a role in the relation found. Several studies indeed show a positive although small effect of parental income on child development (e.g., Aughinbaugh and Gittleman 2003: Blau 1999). In Brooks-Gunn, Han, and Waldfogel (2010) it is shown

\footnotetext{
${ }^{29}$ Since we do not find a significant difference between the test scores for girls with fulltime working mothers and girls with mothers with a large part-time job, a larger sample size would probably result in a significant coefficient for full-time maternal employment as well.
} 
that maternal employment is positively associated with mothers' earnings and that this offsets the negative direct association between early maternal employment and child outcomes at age 4.5 in the United States.

Another channel through which maternal work hours and child outcomes may be related, is the quality of the home environment. At work, mothers may exchange information and experience regarding time allocation, good child care centers, and child-raising activities with their colleagues. So, whereas joint parent-child activities do not explain the relation between maternal work status and child outcomes, the quality of parent-child interactions may be important. The quality of parent-child activities may also be higher, because mothers who work are happier and reflect this in their parenting. Especially for the generation of mothers analyzed in this study, women may be happier when they are able to combine family life with a paid (part-time) job. However, while several studies have addressed the question of whether partnered women in the Netherlands prefer part-time jobs over full-time jobs (e.g., Booth and Van Ours 2010; Bosch, Deelen, and Euwals 2010; Portegijs, Cloïn, Ooms, and Eggink 2006), we are not aware of any studies that have analyzed whether working mothers are indeed happier than non-working mothers in the Netherlands. Recently, Berger (2012) showed that in Germany full-time working mothers are more satisfied with their lives than mothers who are not working due to family reasons and mothers in short part-time jobs (less than 20 hours per week). On the other hand, Johnson et al. (2012) found that maternal work accompanied by job stability versus instability and jobs that do or do not require cognitive skills have differentiated effects for children's cognitive and non-cognitive skills. 
Our findings suggest that a high rate of labor market participation among mothers of school-aged children is positively related to the cognitive development, provided that mothers work for a substantial number of hours (at least in a large part-time job). This is an important conclusion, since research (e.g., Currie and Thomas 2001) has shown that early child outcomes are good predictors of economic outcomes at later ages.

Moreover, our findings suggest that governments may encourage mothers of school-aged children to re-enter the labor market or increase their work hours, since maternal employment is positively associated with child outcomes. Especially in the Netherlands, but also in Germany, mothers do not usually return to their pre-maternity work hours, even after their children are older and start school (Bosch, Deelen, and Euwals $2010 ;$ Paull 2008). From the point of view of children's cognition, the average work week among Dutch mothers with school-aged children could be extended like it is in other European countries. 


\section{References}

Andrabi, T., J. Das, A. Khwaja, and T. Zajonc (2011): "Do valueAdded estimates add value? Accounting for learning dynamics," American Economic Journal: Applied Economics, 3(3), 29-54.

Aughinbaugh, A., And M. Gittleman (2003): "Does Money Matter? A Comparison of the Effect of Income on Child Development in the United States and Great Britain," The Journal of Human Resources, 38(2), 416440.

Baum, C. L. (2003): "Does Early Maternal Employment Harm Child Development? An Analysis of the Potential Benefits of Leave Taking," Journal of Labor Economics, 21(2), 381-408.

Berger, E. (2012): "Happy Working Mothers? Investigating the Effect of Maternal Employment on Life Satisfaction," Economica.

Bianchi, S. (2000): "Maternal Employment and Time with Children: Dramatic Change or Surprising Continuity?," Demography, 37(4), 401-414.

Blau, D. (1999): "The Effect of Income on Child Development," Review of Economics and Statistics, 81(2), 261-276.

Booth, A., And J. Van Ours (2010): "Part-Time Jobs: What Women Want?," IZA Discussion Paper 4686.

Bosch, N., A. Deelen, and R. Euwals (2010): "Is Part-time Employment Here to Stay? Working Hours of Dutch Women over Successive Generations," Labour, 24(1), 35-54.

Brooks-Gunn, J., W. Han, and J. WAldfogel (2002): "Maternal employment and child cognitive outcomes in the first three years of life: The NICHD study of early child care," Child Development, 73(4), 1052-1072.

Brooks-Gunn, J., W.-J. Han, and J. Waldfogel (2010): "VII. Structural equation modeling analyses of the links between 1st-year maternal employment and child development," Monographs of the Society for Research in Child Development, 75(2), 83-95.

Carneiro, P., C. Meghir, M. Parey, and G. Street (2007): "Maternal education, home environments and the development of children and adolescents," IZA Discussion Paper 3072, forthcoming in Journal of European Economic Association 2012. 
Cawley, J., And F. Liu (2007): "Mechanisms for the Association between Maternal Employment and Child Cognitive Development," NBER Working Paper 13609.

CBS (2003): Jeugd 2003, cijfers en feiten. CBS.

Currie, J., and D. Thomas (2001): "Early Test Scores, Socioeconomic Status, School Quality and Future Outcomes," Research in Labor Economics, 20, 103-132.

Desai, S., P. Chase-Lansdale, and R. Michael (1989): "Mother or market? Effects of maternal employment on the intellectual ability of 4year-old children," Demography, 26(4), 545-561.

Ermisch, J., and M. Francesconi (2000): "The Effect of Parents' Employment on Children's Educational Attainment," IZA Discussion Paper 215, forthcoming in Journal of Applied Econometrics 2012.

Fouarge, D., and R. Muffels (2008): "Part-Time Work and Childbirth in Europe: Scarring the Career or Meeting Working-Time Preferences?," in Flexibility and Employment Security in Europe: Labour Markets in Transition, ed. by R. Muffels, pp. 223-254. Edward Elgar, UK: Cheltenham.

Fox, L., W.-J. Han, C. Ruhm, and J. Waldfogel (2013): "Time for Children: Trends in the Employment Patterns of Parents, 1967-2009.," Demography, 50, 25-49.

Greenstein, T. N. (1995): "Are the "Most Advantaged" Children Truly Disadvantaged by Early Maternal Employment?: Effects on Child Cognitive Outcomes," Journal of Family Issues, 16(2), 149-169.

Han, W., J. Waldfogel, and J. Brooks-Gunn (2001): "The effects of early maternal employment on later cognitive and behavioral outcomes," Journal of Marriage and Family, 63(2), 336-354.

Harvey, E. (1999): "Short-Term and Long-Term Effects of Early Parental Employment on Children of the National Longitudinal Survey of Youth," Development Psychology, 35(2), 445-459.

Hill, J., J. Waldfogel, J. Brooks-Gunn, and W. Han (2005): "Towards a Better Estimate of the Causal Links in Child Policy: the Case of Maternal Employment and Child Outcomes," Development Psychology, 41(6), 833-850. 
Johnson, R. C., A. Kalil, and R. E. Dunifon (2012): "Employment Patterns of Less-Skilled Workers: Links to Children's Behavior and Academic Progress," Demography, pp. 1-26.

Jungbluth, P., And R. Rodigas (2011): "Kleuter in Zuid-Limburg: Hoe Staan de Kansen? Regiobrede 'Nulmeting' bij de Start van de ZuidLimburgse Pilot voor Voorschoolse Educatie 'Moelejaan'," Discussion paper, Maastricht University.

Kornrich, S., And F. Furstenberg (2013): "Investing in Children: Changes in Parental Spending on Children, 1972-2007," Demography, 50, $1-23$.

O'Brien, M., And D. Jones (1999): "Children, Parental Employment and Educational Attainment: An English Case Study," Cambridge Journal of Economics, 23(5), 599-621.

Parcel, T., and E. Menaghan (1994): Parents' Jobs and Children's Lives. Adline de Gruyter, USA: New York.

Paull, G. (2008): "Children and Women's Hours of Work," The Economic Journal, 118(526), F8-F27.

Portegiss, W., M. Clö̈n, I. Ooms, and E. Eggink (2006): "Hoe het Werkt met Kinderen. Moeders over Kinderopvang en Werk," SCP Publication 2006/5.

Rosenzweig, M., And K. Wolpin (1995): "Sisters, Siblings, and Mothers: The Effect of Teen-Age Childbearing on Birth Outcomes in a Dynamic Family Context," Econometrica, 63(2), 303-326.

Ruhm, C. (2008): "Maternal Employment and Adolescent Development," Labour Economics, 15(5), 958-983.

Ruhm, C. J. (2004): "Parental Employment and Child Cognitive Development," Journal of Human Resources, 39(1), 155-192.

Rutter, M. (1985): "Family and school influences on cognitive development," Journal of Child Psychology and Psychiatry, 26(5), 683-704.

Sastry, N., And A. R. Pebley (2010): "Family and neighborhood sources of socioeconomic inequality in children's achievement," Demography, 47(3), $777-800$. 
TodD, P., And K. Wolpin (2007): "The production of cognitive achievement in children: Home, school, and racial test score gaps," Journal of Human capital, 1(1), 91-136.

VAndell, D., And J. Ramanan (1992): "Effects of Early and Recent Maternal Employment on Children from Low-Income Families," Child Development, 63(4), 938-949.

Zaslow, M., and C. HAYES (1986): "Sex differences in children's response to psychosocial stress: Toward a cross-context analysis," in Advances in developmental psychology, ed. by M. Lamb, A. Brown, and B. Rogoff, vol. 4, pp. 285-337. Lawrence Erlbaum, Hillsdale, N.J. 


\section{Tables and figures}

Table 1: Labor force participation and average work hours of mothers by age of youngest child

\begin{tabular}{llllll}
\hline \hline & $\begin{array}{l}\text { Nether- } \\
\text { lands }\end{array}$ & $\begin{array}{l}\text { United } \\
\text { Kingdom }\end{array}$ & Germany & France & Spain \\
Labor force participation (\%) & & & & & \\
0-4 years old & 72 & 60 & 44 & 62 & 53 \\
5-9 years old & 74 & 75 & 65 & 74 & 55 \\
10-14 years old & 75 & 79 & 74 & 75 & 54 \\
& & & & & \\
Average work week (hours) & & & & & \\
0-4 years old & 22 & 25 & 24 & 32 & 31 \\
5-9 years old & 20 & 25 & 22 & 32 & 32 \\
10-14 years old & 21 & 28 & 23 & 32 & 32 \\
& & & & & \\
\hline \hline
\end{tabular}

Source: EU LFS 2005

Note: Average work hours are calculated among the working mothers.

Table 2: Sample size per tests and children's gender

\begin{tabular}{llll}
\hline \hline \multicolumn{3}{c}{ Sample for } \\
& Language outcomes & Sorting outcomes & Total sample \\
\hline Total & 2260 & 1895 & 2315 \\
\hline Girls & 1125 & 943 & 1153 \\
Boys & 1135 & 952 & 1162 \\
\hline \hline
\end{tabular}

Note: As we do not have both type of test scores for each child, the two samples relating to child outcomes differ in size. Every child who is in the sample for the time investments, is part of either the language or the sorting sample as well. 
Table 3: Summary statistics of raw test scores year 2

\begin{tabular}{rrrrrr}
\hline & $\mathrm{N}$ & Mean & Sd. Dev & Min. & Max. \\
\hline Language test & 2260 & 47.4 & 5.4 & 21 & 56 \\
\hline Girls & 1125 & 47.7 & 5.4 & 23 & 56 \\
Boys & 1135 & 47.1 & 5.4 & 21 & 56 \\
\hline Sorting test & 1895 & 33.7 & 4.6 & 14 & 42 \\
\hline Girls & 943 & 33.9 & 4.5 & 16 & 42 \\
Boys & 952 & 33.5 & 4.7 & 14 & 42 \\
\hline \hline
\end{tabular}

Note: This table reports the number of good answers in the language and sorting test. The total number of questions in the language test equals 56 , the total number of questions in the sorting test equals 42 .

Figure 1: Parental work status

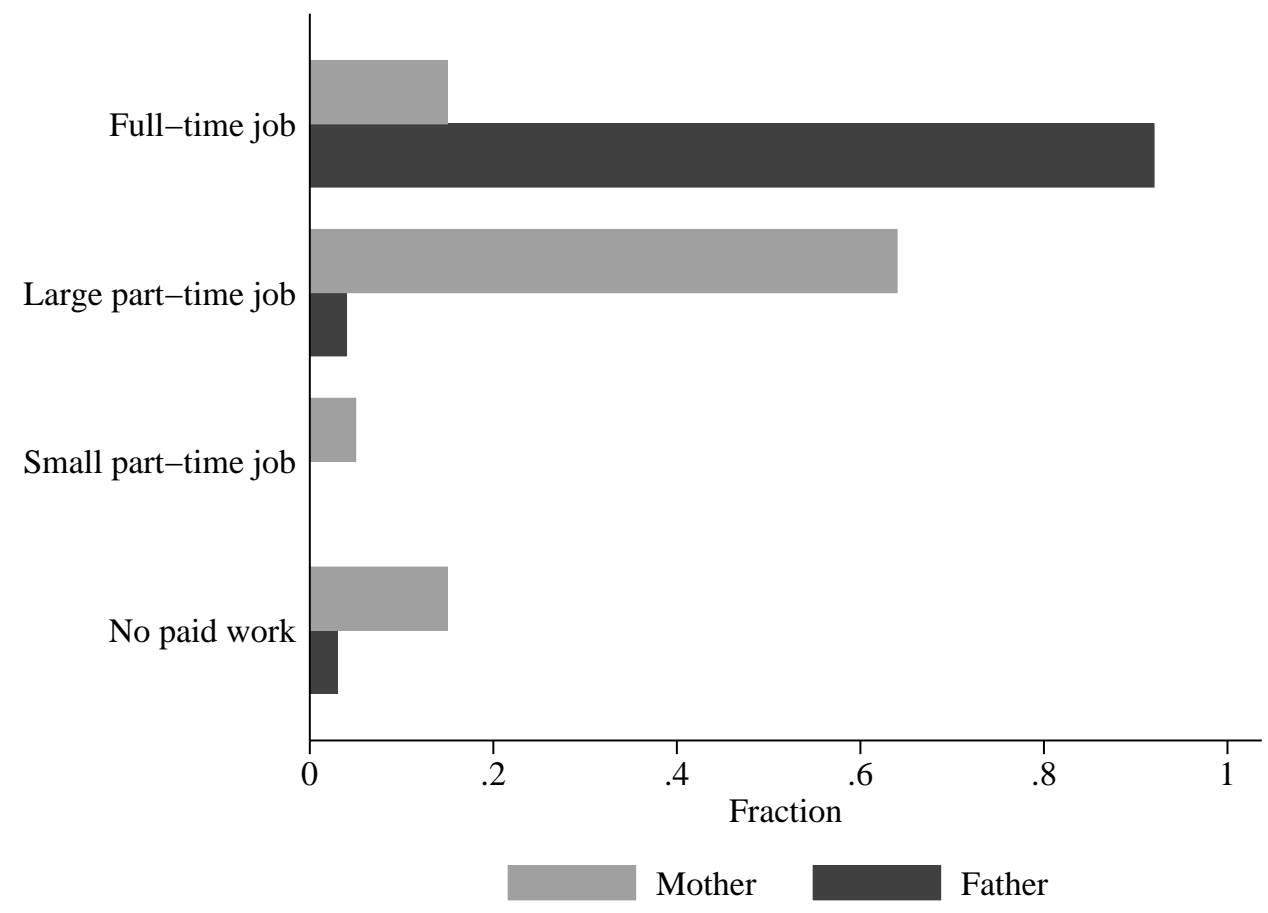


Figure 2: Distribution of joint parent-child activities

(a) Joint daily activities

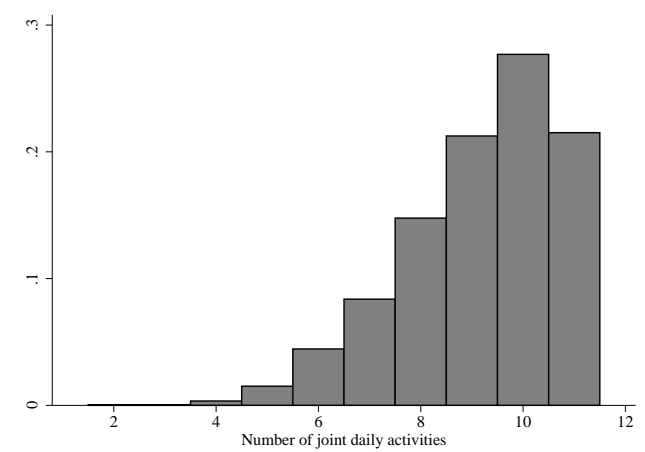

(b) Joint planned activities

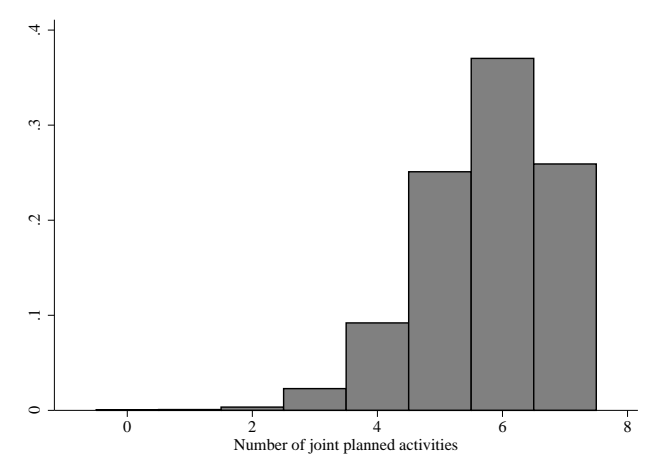

Figure 3: Distribution of language test score by maternal work status and gender

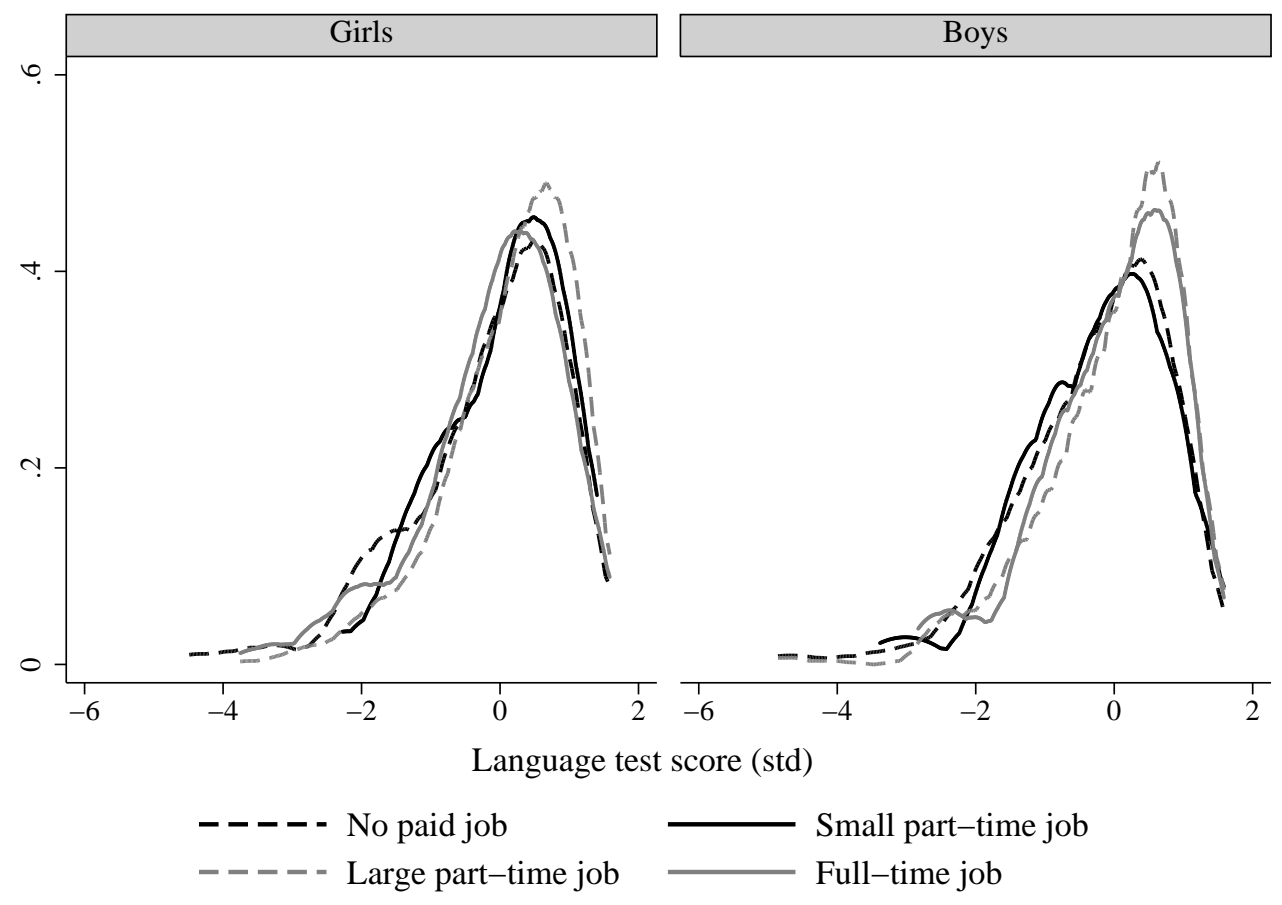


Figure 4: Distribution of sorting test score by maternal work status and gender

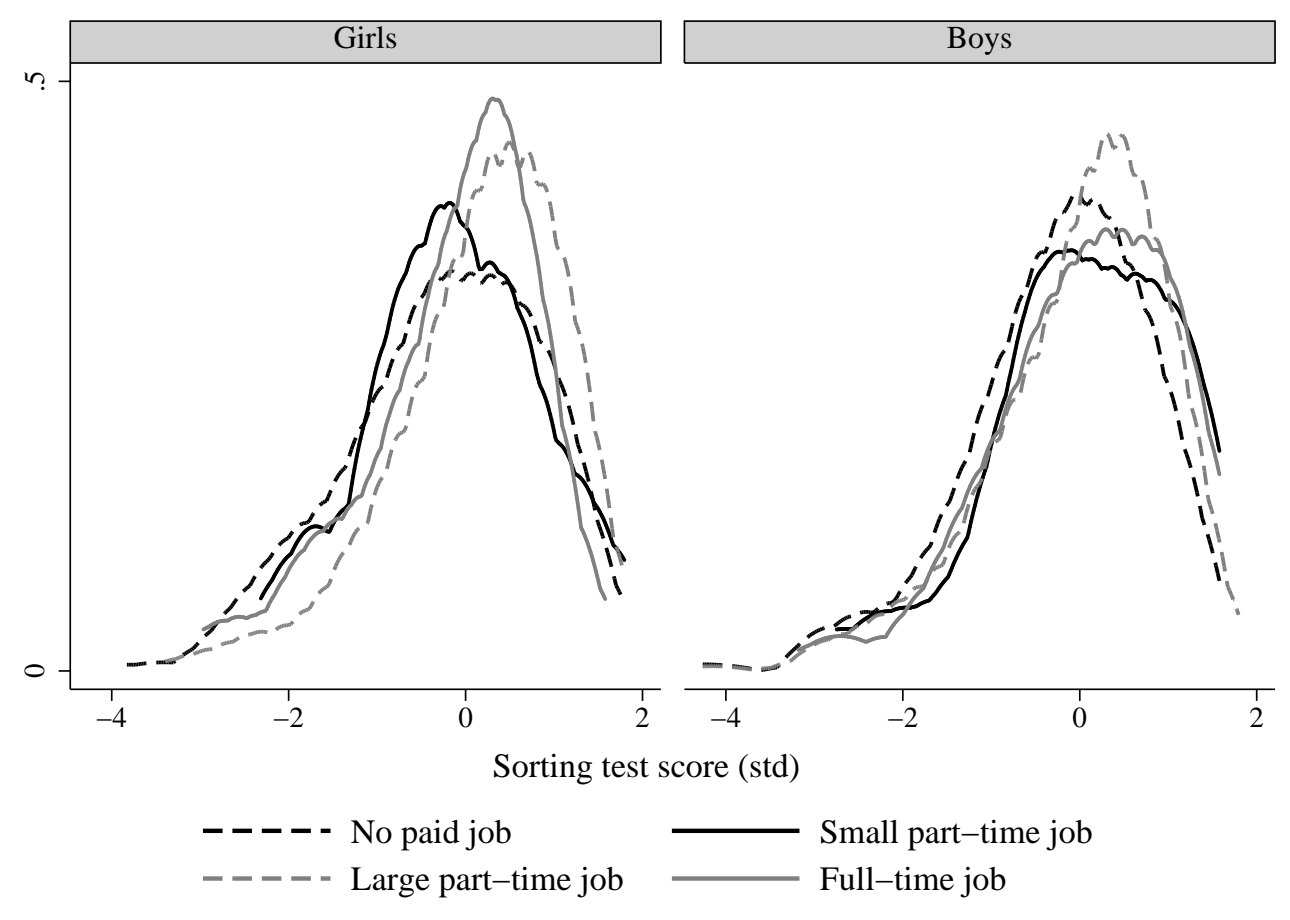


Table 4: OLS results on the language test in the second school year

\begin{tabular}{|c|c|c|c|c|}
\hline \multirow{4}{*}{$\begin{array}{l}\text { Dep. Var.: Language test score year } 2 \text { (std) } \\
\text { Small part-time job }\end{array}$} & \multicolumn{2}{|c|}{ Girls } & \multicolumn{2}{|c|}{ Boys } \\
\hline & (1) & $(2)$ & $(3)$ & $(4)$ \\
\hline & 0.104 & 0.090 & 0.052 & 0.049 \\
\hline & $(0.137)$ & $(0.137)$ & $(0.140)$ & $(0.140)$ \\
\hline \multirow[t]{2}{*}{ Large part-time job } & 0.068 & 0.063 & 0.067 & 0.070 \\
\hline & $(0.080)$ & $(0.080)$ & $(0.076)$ & $(0.076)$ \\
\hline \multirow[t]{2}{*}{ Full-time job } & -0.042 & -0.052 & 0.138 & 0.148 \\
\hline & $(0.100)$ & $(0.100)$ & $(0.097)$ & $(0.097)$ \\
\hline \multirow[t]{2}{*}{ Education level mother } & $0.043^{* * *}$ & $0.039^{* * *}$ & $0.049 * * *$ & $0.046^{* * *}$ \\
\hline & $(0.014)$ & $(0.014)$ & $(0.015)$ & $(0.015)$ \\
\hline \multirow[t]{2}{*}{ Education level father } & -0.016 & -0.017 & 0.016 & 0.013 \\
\hline & $(0.013)$ & $(0.013)$ & $(0.014)$ & $(0.014)$ \\
\hline \multirow[t]{2}{*}{ Language test score year 1 (std) } & $0.487^{* * *}$ & $0.483^{* * *}$ & $0.411^{* * *}$ & $0.408^{* * *}$ \\
\hline & $(0.030)$ & $(0.030)$ & $(0.030)$ & $(0.030)$ \\
\hline \multirow[t]{2}{*}{ Daily parent-child activities } & & 0.014 & & -0.004 \\
\hline & & $(0.018)$ & & $(0.017)$ \\
\hline \multirow[t]{2}{*}{ Planned parent-child activities } & & $0.051^{*}$ & & $0.061^{* *}$ \\
\hline & & $(0.026)$ & & $(0.027)$ \\
\hline Adjusted R-squared & 0.193 & 0.195 & 0.156 & 0.158 \\
\hline $\mathrm{N}$ & 1125 & 1125 & 1135 & 1135 \\
\hline Child characteristics & yes & yes & yes & yes \\
\hline Family characteristics & yes & yes & yes & yes \\
\hline School fixed effects & yes & yes & yes & yes \\
\hline
\end{tabular}

Note: all specifications include mother, father, child, household characteristics as well as parental values and parenting goals. Standard errors in parentheses; ${ }^{*} \mathrm{p}<0.1 ;{ }^{* *} \mathrm{p}<0.05 ;{ }^{* *} \mathrm{p}<0.01$. 
Table 5: OLS results on the sorting test in the second school year

\begin{tabular}{lllll}
\hline \hline & \multicolumn{3}{c}{ Girls } & \multicolumn{2}{c}{ Boys } \\
Dep. Var.: Sorting test score year 2 (std) & $(1)$ & $(2)$ & $(3)$ & $(4)$ \\
Small part-time job & -0.042 & -0.038 & 0.200 & 0.190 \\
& $(0.151)$ & $(0.151)$ & $(0.164)$ & $(0.165)$ \\
Large part-time job & $0.176^{* *}$ & $0.177^{* *}$ & 0.034 & 0.032 \\
& $(0.085)$ & $(0.085)$ & $(0.086)$ & $(0.086)$ \\
Full-time job & 0.061 & 0.067 & $0.297^{* * *}$ & $0.296^{* * *}$ \\
& $(0.108)$ & $(0.109)$ & $(0.110)$ & $(0.110)$ \\
Education level mother & 0.016 & 0.017 & -0.001 & -0.001 \\
& $(0.015)$ & $(0.016)$ & $(0.017)$ & $(0.017)$ \\
Education level father & 0.006 & 0.007 & $0.040^{* * *}$ & $0.041^{* * *}$ \\
& $(0.014)$ & $(0.014)$ & $(0.015)$ & $(0.016)$ \\
Sorting test score year 1 (std) & $0.483^{* * *}$ & $0.484^{* * *}$ & $0.421^{* * *}$ & $0.421^{* * *}$ \\
& $(0.032)$ & $(0.032)$ & $(0.034)$ & $(0.034)$ \\
Daily parent-child activities & & -0.012 & & 0.011 \\
& & $(0.019)$ & & $(0.020)$ \\
Planned parent-child activities & & -0.014 & & 0.002 \\
& & $(0.028)$ & & $(0.031)$ \\
\hline Adjusted R-squared & 0.214 & 0.213 & 0.124 & 0.122 \\
N & 943 & 943 & 952 & 952 \\
\hline Child characteristics & yes & yes & yes & yes \\
Family characteristics & yes & yes & yes & yes \\
School fixed effects & yes & yes & yes & yes \\
\hline \hline
\end{tabular}

Note: all specifications include mother, father, child, household characteristics as well as parental values and parenting goals. Standard errors in parentheses; ${ }^{*} \mathrm{p}<0.1{ }^{* *} \mathrm{p}<0.05 ;{ }^{* *} \mathrm{p}<0.01$. 
Appendix

Descriptives 
Figure 5: Distribution of test scores for sample and population

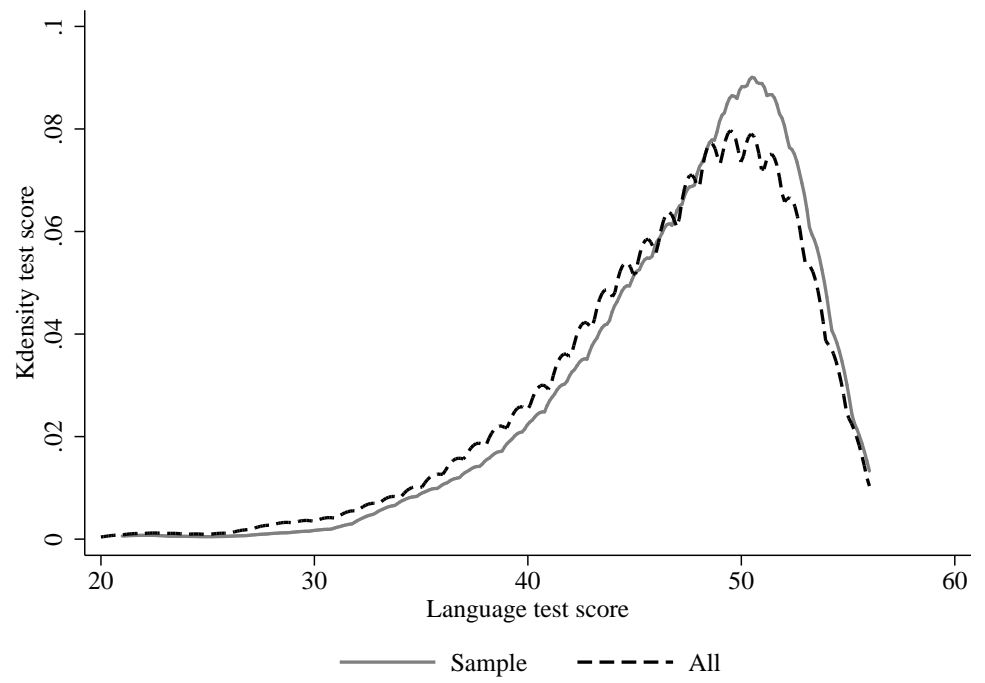

(a) Language test

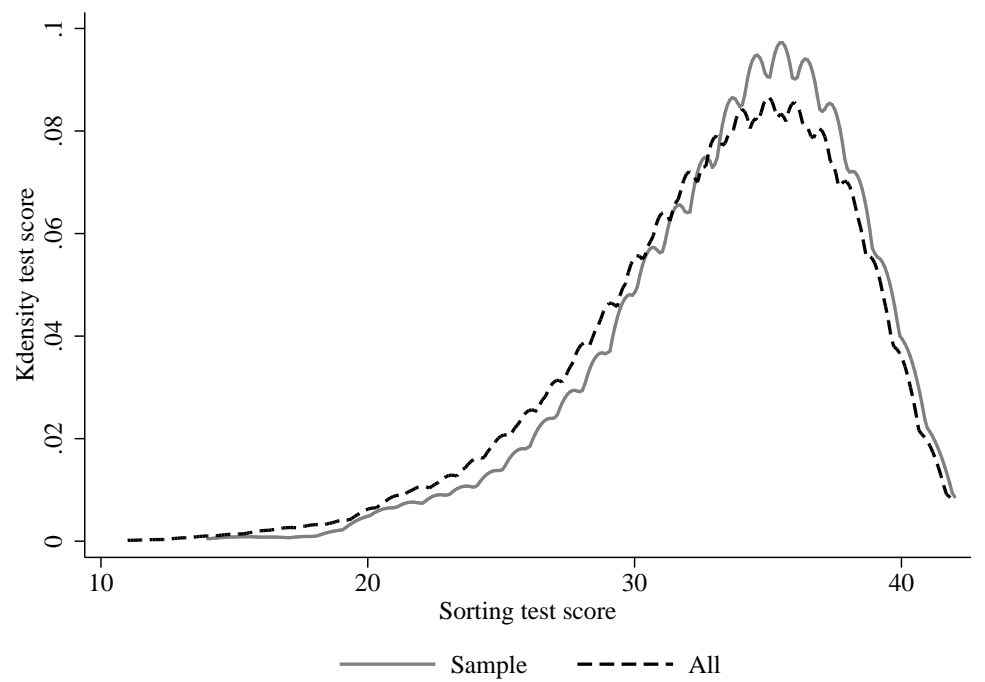

(b) Sorting test 
Table 6: Summary statistics of raw test scores year 1

\begin{tabular}{rrrrrr}
\hline \hline & $\mathrm{N}$ & Mean & Sd. Dev & Min. & Max. \\
\hline Language test & 2260 & 38.5 & 5.2 & 15 & 48 \\
\hline Girls & 1125 & 38.9 & 5.1 & 15 & 48 \\
Boys & 1135 & 38.1 & 5.2 & 18 & 48 \\
\hline Sorting test & 1895 & 33.4 & 5.7 & 12 & 42 \\
\hline Girls & 943 & 33.7 & 5.7 & 13 & 42 \\
Boys & 952 & 33.1 & 5.8 & 12 & 42 \\
\hline \hline
\end{tabular}

Note: This table reports the number of good answers in the language and sorting test in the first school year. The total number of questions in the language test equals 48 , the total number of questions in the sorting test equals 42 .

Table 7: Summary statistics of control variables by gender of child

\begin{tabular}{|c|c|c|c|c|c|}
\hline & $\mathrm{N}$ & Mean & Std. Dev. & Min & Max \\
\hline Education level mother & 2315 & 6.39 & 2.22 & 0 & \\
\hline Year of birth mother & 2315 & 1971 & 3.89 & 1960 & 1998 \\
\hline Mother speaks Dutch with the child & 2315 & 0.95 & 0.22 & 0 & 1 \\
\hline Education level father & 2315 & 6.51 & 2.36 & 0 & 9 \\
\hline Year of birth father & 2315 & 1969 & 4.06 & 1959 & 1985 \\
\hline Father speaks Dutch with the child & 2315 & 0.95 & 0.22 & 0 & 1 \\
\hline Gender & 2315 & 0.50 & 0.50 & 0 & 1 \\
\hline Number of children living in the household & 2315 & 3.09 & 0.71 & 1 & 7 \\
\hline Are there any grandmoms/dads living in the household? & 2273 & 0.01 & 0.09 & 0 & 1 \\
\hline Are there any aunts/uncles living in the household? & 2214 & 0.00 & 0.04 & 0 & 1 \\
\hline Are there any other adults living in the household? & 2212 & 0.00 & 0.06 & 0 & 1 \\
\hline Cohort & 2315 & 2.48 & 0.50 & 2 & 3 \\
\hline Child speaks Dutch with friends & 2315 & 0.99 & 0.11 & 0 & 1 \\
\hline $\begin{array}{l}\text { Did a fundamental event occur that affected } \\
\text { child's development? }\end{array}$ & 2315 & 0.06 & 0.23 & 0 & 1 \\
\hline Extent to which child has difficulties with emotions & 2290 & 0.19 & 0.45 & 0 & 3 \\
\hline Extent to which child has difficulties with concentration & 2291 & 0.29 & 0.56 & 0 & 3 \\
\hline Extent to which child has difficulties with behavior & 2289 & 0.15 & 0.40 & 0 & 3 \\
\hline $\begin{array}{l}\text { Extent to which child has difficulties with dealing } \\
\text { with other people }\end{array}$ & 2278 & 0.07 & 0.30 & 0 & 3 \\
\hline
\end{tabular}

Note: Whereas the sample size is 2315 , some variables in the table have lower numbers of observations. This is due to missing values. In the analyses, we include dummy variables for all possible values of these values, including a dummy for missing values. Other control variables not mentioned in the table are standardized (factor) variables with mean equal to zero and a standard deviation equal to one. It concerns parental views, parenting goals, and the four noncognitive skills (inquisitive, individual, difficult and sociable). Moreover, the table excludes summary statistics on mothers', fathers' and children's religion as we include several religion dummies that are not so informative. 
Factor analyses 
Table 8: Factor loadings on children's non-cognitive skills

\begin{tabular}{|c|c|c|c|c|}
\hline$\overline{\text { Items }}$ & Factor 1 & Factor 2 & Factor 3 & $\overline{\text { Factor } 4}$ \\
\hline & Inquisitive & Individual & Difficult & Sociable \\
\hline Oriented towards other children & & & 0.3033 & 0.7324 \\
\hline Adapts easily & & & & 0.6226 \\
\hline Independent & & 0.7464 & & \\
\hline Smart & 0.4799 & & & \\
\hline Imagination in somebody else's situation & & 0.7225 & & \\
\hline Chaotic & & 0.4895 & & \\
\hline Easygoing & & 0.7463 & & \\
\hline Can amuse oneself & & & 0.5426 & \\
\hline Focussed on herself/ himself & & & & 0.7062 \\
\hline Cheerful & & & & 0.7318 \\
\hline To be quick on the uptake & 0.5033 & & & \\
\hline Friskily & 0.7846 & & & \\
\hline Complaining & 0.7523 & & & \\
\hline Quiet & 0.4906 & 0.3309 & & \\
\hline Bothersome & 0.3484 & & 0.4554 & \\
\hline Talks a lot & & 0.312 & 0.6138 & \\
\hline Precise & & & -0.3269 & \\
\hline Frivolous & & & & \\
\hline Nice & & 0.4649 & & \\
\hline Scared & & & & 0.3543 \\
\hline Leisurely & 0.7631 & & & \\
\hline Creative & 0.7901 & & & \\
\hline Thoughtful & 0.7683 & & & \\
\hline Systematic & 0.3622 & & 0.5873 & \\
\hline Timid & & 0.3697 & 0.3454 & \\
\hline Spontaneous & & & 0.3056 & \\
\hline Gripped & & & 0.7254 & \\
\hline Easy & -0.4006 & 0.6226 & & \\
\hline Irascible & & & 0.7804 & \\
\hline Inquisitive & 0.3997 & & & \\
\hline Interested & 0.5996 & & & \\
\hline Active & & 0.6686 & & \\
\hline Nasty & 0.7181 & & & \\
\hline Gets tired easily & & 0.3858 & 0.3532 & \\
\hline Keeps distance & & & 0.5976 & \\
\hline Kind & & & & 0.5168 \\
\hline Slowly & -0.3066 & 0.364 & 0.604 & 0.3539 \\
\hline Reserved & & 0.6904 & & \\
\hline Contacts others easily & 0.8021 & & & \\
\hline Jumpy & & 0.4155 & 0.4582 & \\
\hline Healthy & 0.6826 & & & \\
\hline Imaginative & 0.6642 & & & \\
\hline
\end{tabular}


Table 9: Factor loadings on parental views

\begin{tabular}{lr}
\hline \hline & Factor 1 \\
To what extent do you agree/disagree to the following statements: & Parental views \\
Going to college is more important for boys than for girls. & 0.2290 \\
Marriage is old-fashion. & 0.0276 \\
Our children will have a better life than we have . & 0.3506 \\
Home work is at least as satisfying as is paid work. & 0.2072 \\
Men are often better politicians than women. & 0.5067 \\
Children need a family with both a mother and a father. & 0.2267 \\
Religion is very important to me. & 0.2360 \\
I am jealous at the opportunities of the youngest generation. & 0.3122 \\
Children need to be prepared to school at an early stage. & 0.2871 \\
Early child care is important for children's development. & 0.0754 \\
It is important that children do well at school. & 0.4049 \\
Women are allowed to be mother without a stable relationship. & -0.2948 \\
Men do mostly a better job in managing occupations. & 0.5449 \\
My child needs to go to a school nearby. & 0.1287 \\
I assume that our children will have a better life than we have. & 0.2966 \\
At school children should have to work hard. & 0.3635 \\
\hline \hline
\end{tabular}

Table 10: Factor loadings on parenting goals

\begin{tabular}{lr}
\hline \hline & Factor 1 \\
How important is it to you that your child learns: & Parenting goals \\
to be economical & 0.4436 \\
to know what is going on in the world & 0.4309 \\
to be hardworking & 0.3737 \\
to stand one's ground & 0.4038 \\
to take time for her/hisself & 0.6110 \\
to fight for her/hisself & 0.5967 \\
to develop imagination & 0.5304 \\
to indulge her/hisself & 0.5629 \\
to be tolerant towards others' opinions & 0.5792 \\
to be independent & 0.5575 \\
to not let her/hisself be rushed & 0.6073 \\
to be satisfied with what she/he has & 0.6081 \\
to show persistence & 0.5884 \\
to be religious & 0.2766 \\
to show solidarity & 0.5129 \\
to obey & 0.4628 \\
\hline \hline
\end{tabular}




\section{Robustness analyses}

Table 11: Robustness checks

\begin{tabular}{|c|c|c|c|c|c|c|}
\hline & \multicolumn{3}{|c|}{ Girls } & \multicolumn{3}{|c|}{ Boys } \\
\hline & PT small & PT large & FT & PT small & PT large & FT \\
\hline \multicolumn{7}{|l|}{ Sorting } \\
\hline \multirow[t]{2}{*}{ Basic value added model } & -0.029 & $0.176^{* *}$ & 0.062 & 0.192 & 0.033 & $0.297^{* * *}$ \\
\hline & $(0.151)$ & $(0.085)$ & $(0.109)$ & $(0.165)$ & $(0.086)$ & $(0.110)$ \\
\hline \multirow[t]{2}{*}{ Instrumented lagged test score } & -0.054 & $0.175^{* *}$ & 0.125 & 0.183 & 0.004 & $0.275^{* * *}$ \\
\hline & $(0.140)$ & $(0.078)$ & $(0.101)$ & $(0.148)$ & $(0.078)$ & $(0.099)$ \\
\hline \multicolumn{7}{|l|}{ Language test score } \\
\hline \multirow[t]{2}{*}{ Basic value added model } & 0.090 & 0.059 & -0.051 & 0.048 & 0.072 & 0.152 \\
\hline & $(0.136)$ & $(0.080)$ & $(0.100)$ & $(0.140)$ & $(0.076)$ & $(0.097)$ \\
\hline \multirow[t]{2}{*}{ Instrumented lagged test score } & 0.219 & 0.131 & 0.008 & 0.106 & 0.073 & 0.161 \\
\hline & $(0.174)$ & $(0.099)$ & $(0.126)$ & $(0.169)$ & $(0.089)$ & $(0.114)$ \\
\hline
\end{tabular}

Note: Each row reports estimation results of one specification, separately for girls and boys. The two models are explained in Section 3 All specifications include mother, father, child, household characteristics as well as parental values and parenting goals. Standard errors in parentheses; ${ }^{*} \mathrm{p}<0.1 ;{ }^{*} \mathrm{p}<0.05 ;{ }^{* * *} \mathrm{p}<0.01$. 